Ethiopian Journal of Environmental Studies \& Management 8(1): 97 - 106, 2015.

ISSN:1998-0507

doi: http://dx.doi.org/10.4314/ejesm.v8i1.9

Submitted: November 04, 2014

Accepted: January 19, 2015

\title{
EFFICACY OF MODIFIED POLYCROSS METHOD IN DEVELOPMENT OF SUGARCANE PROGENIES
}

*ATANDA, A.S., OLAOYE, G. AND AMUDA, A.

Department of Agronomy/Sugar Research Institute, University of Ilorin, PMB 1515, Ilorin

Nigeria

\begin{abstract}
There has not been appreciable progress in development of productive commercial sugarcane varieties in Nigeria due to low technological development. Consequently, a modified polycross breeding scheme was developed to generate superior progenies that could replace existing low yielding varieties. The objective of this study therefore was to test the efficacy of the breeding scheme by assessing the genetic variability and inheritance of characters associated with economic sugarcane traits (cane yield and sucrose content) among the progenies as well as identify those with superior performance over the best checks. The results showed significant differences $(P 0.05 \leq 0.001)$ for all the traits as well as the presence of high genetic variability for the studied traits except for brix among the progenies. Rank summation index based on the combination of cane yield and brix, identified three progenies USRI/08/12, USRI/08/22 and USRI/08/25 as being superior to the highest yielding check varieties. The results showed that the modified polycross method is as efficient as the Hawaiian polycross technique and more economical in the development of high yielding commercial sugarcane varieties in low technological developed sugarcane breeding programme.
\end{abstract}

Key Words: Crop cycles, Heritability, Rank Summation Index, Saccharum officinarum L.

\section{Introduction}

Commercial sugarcane varieties are highly polyploidy with complex genome (Falconer, 1966; Olaoye, 1995). The heterozygous and polyploidy of this crop is a source of great genetic variability (Falconer, 1966). Knowledge of genetic variability that can represent the potential of the population for the selection and heritability are of great importance for the estimation of the genetic gain, success in the selection and development of new cultivars (Olaoye, 1995; Ramalho et al., 2004). For example, the simplest selection method can be used when the heritability is high or more sophisticated methods are

*Corresponding Author: Atanda, S.A.

Email: sikiruandfriends@gmail.com necessary when it is low such as best linear unbias prediction (BLUP) and simulated individual BLUP (BLUPIS) (Resende and Barbosa, 2006).

Several studies have been undertaken in sugarcane to estimate heritability of both quantitative and qualitative traits. For example, studies conducted in Nigeria, have provided heritability estimates ranging from moderate $(0.49 \%)$ to high $(\geq 70 \%)$ for cane yield and associated traits and from $0.16 \%$ to $0.42 \%$ for brix. However, these estimates have also varied depending on the population being sampled (Olaoye and Fatunla, 1991; Olaoye, 1995; 2001; Ishaq and Olaoye, 2006), crop cycles (Olaoye, 
2005) and/or environmental conditions under which the genetic materials were evaluated (Olaoye, 2006; Ishaq and Olaoye, 2008). Similarly, studies conducted elsewhere (Singh et al., 1981, 1983; Chaudhary, 2001; Soomoro et al., 2006) have also shown that most of the traits contributing to quantitative and/or qualitative characters have moderate to high heritability depending on the environment where such study was undertaken. For example, Singh et al., (1981, 1983) reported heritability estimates ranging from 0.47 to 0.76 in plant cane and 0.56 to 0.83 in the first ratoon respectively for brix (total soluble solid) and purity percent extraction. Chaudhary (2001) in his own study reported high heritability estimates for millable cane population $(88 \%)$, stalk diameter $(85 \%)$ and sugarcane weight $(84 \%)$ whereas low heritability estimates were recorded for germination at 45 days after planting (45\%) and sucrose in the juice (32\%).

Over the past fifty years, the Nigerian sugar industry depended solely on importation of refined sugar (FAOSTAT, 2011) to meet local consumption requirements, probably due to lack of high yielding and adaptable commercial sugarcane varieties. Thus, it is important to develop sugarcane varieties that can effectively serve the Nigerian sugar industries in the face of low technological development. The modified ploycross breeding scheme was developed at the Unilorin Sugar Research Institute (USRI) to cater for lack of specialized glasshouse and sulphurous acid solution necessary for effective hybridization under a controlled environment devoid of contamination from unwanted pollen source in Nigeria (Olaoye, 2001). Briefly, the scheme comprised of grouping all available male and female parents in the germplasm into early, mid and late flowering (arrowing) groups, followed by establishment of crossing blocks on the field among male and female parents whose arrowing period could be synchronized while maintaining sufficient isolation distance from the nearest sugarcane field. Previous study which evaluated the efficiency of the breeding scheme (Olaoye, 2001) has shown that the breeding scheme could be as efficient as the Hawaiian polycross technique in the development of superior sugarcane varieties. The present study assessed the performance of ninety-seven progenies from the breeding scheme which are currently in stage one selection stage over three cropping cycles with the objective of further testing the efficacy of the technique (the modified polycross method). Through assessment of the genetic variability and inheritance of characters associated with economic sugarcane traits (cane yield and sucrose content) in a set of progenies developed by the breeding scheme.

\section{Materials and Method}

Crosses were set up in the field between 36 male sterile clones (maternal parents) and several male fertile clones (paternal parents) at the research farm of the Unilorin Sugar Research Institute (USRI) - Lat. $08^{\circ}$ 26'N, Long. 04 ${ }^{\circ}$ 29'E, approximately $344.70 \mathrm{~mm}$ above the sea level in January, 2006. The layout of the modified polycross scheme has been described elsewhere (Olaoye, 2001). Briefly, the female parents were planted in single rows, $3 \mathrm{M}$ long while the males consisting of the mixtures of stalks of all male parental clones in the outer rows but with sufficient isolation distance from the nearest sugarcane field. Fuzz (true sugarcane seeds) were harvested from the female parents at the end of the arrowing season, teased and stored in Ziploc bags after they have been properly 
identified by the female parentage before being stored in the freezer. The fuzz were later sown into 10 liter plastic pots filled with sterilized topsoil and which were perforated at the bottom to allow for drainage of water in the USRI screen house in January, 2007. All necessary field maintenance practices were carried out (including supply of dissolved nutrient solution) to ensure maximum survival of the seedlings. The seedlings were later transferred to polythene bags and finally into the breeding nursery according to the maternal parent out of which a total of 350 healthy and vigorous progenies derived from the 36 maternal parents were finally planted into the field in April of 2007. At the end of the arrowing (flowering) season in 2007, $97 F_{1}$ progenies were finally selected and given the USRI permanent identification code (Table not shown). The progenies along with 13 check varieties were evaluated in a two-replicate randomized complete block design (RCBD) in January 2008. The clones were planted in single row plots, $5 \mathrm{~m}$ long and $1.5 \mathrm{~m}$ between the rows. The fields were irrigated immediately after planting to provide moisture for good crop establishment and growth, until the commencement of the rains. Weed was controlled by hand first at four weeks after planting (WAP) and repeated as necessary until the plant cane was harvested. Fertilizer was applied at the rate of $150 \mathrm{kgha}^{-1}$ to complement the nutrient for the plants in the soil using NPK 15:15:15 compound fertilizer.

The following data were collected from ten (10) selected competitive stools on individual plot basis, prior to harvesting in Jan. 2010 (I) Number of internodes/stalk (II) Stalk length [cm] (III) stalk diameter [cm] (IV) Cane yield [tonsha ${ }^{-1}$ ] (V) ${ }^{0}$ Brix \% juice. Due to the breakdown of the irrigation facilities and delay in commencement of rains in 2010, harvesting of the plant cane was delayed beyond the normal 12 calendar months stipulated for a crop cycle in sugarcane in our breeding programme. The plants were allowed to regrow and the same sets of data were collected for the subsequent ratoon crops in 2010 and 2011 respectively.

\section{Data Analysis}

The data were analyzed on individual plant basis, followed by combine analysis of variance (ANOVA) across harvest stages using GENSAT version 5.32. The model for combine analysis over years is expressed as: $Y i j k=\mu+\mathrm{Gi}+\mathrm{Ek}+\mathrm{Bj}(\mathrm{ek})$ $+\mathrm{GE}(\mathrm{ik})+$ eijk

Where Yijk = observation of the ith genotype in kth environment using jth replicate. $\mu=$ overall mean, $\mathrm{Gi}=$ genotype effect, Ek= effect of the harvest stages, $\mathrm{Bj}=$ replicate effect. $\mathrm{i}=1 \ldots . .97, \mathrm{j}=1,2 . \mathrm{k}=1 \ldots 3$. Estimate of variance components were extracted from expected mean squares as follows:

$$
\begin{aligned}
\delta^{2} \mathrm{e} & =\mathrm{Me} \\
\delta^{2} \mathrm{gcc} & =\frac{\mathrm{Mgcc}-\mathrm{Me}}{\mathrm{r}} \\
\delta^{2} \mathrm{~g} & =\frac{\mathrm{Mg}-\mathrm{Mgcc}}{\mathrm{rcc}} \\
\mathrm{Ph} & =\delta^{2} \mathrm{~g}+\frac{\delta^{2} \mathrm{gcc}}{\mathrm{r}}+\frac{\delta^{2} \mathrm{e}}{\mathrm{rcc}}
\end{aligned}
$$

Where: $r$ and hs were number of replications and harvest stages respectively. $\delta^{2}$ are the appropriate estimates of variance components for error $\left(\delta^{2} \mathrm{e}\right)$, genotype $\mathrm{x}$ crop cycle $\left(\delta^{2} \mathrm{gcc}\right)$, genotype $\left(\delta^{2} \mathrm{~g}\right)$ and phenotype $\left(\delta^{2} \mathrm{ph}\right)$ respectively.

Broad sense heritability was computed as:

$$
\mathrm{H}^{2} \mathrm{~B}=\frac{\delta^{2} \mathrm{~g}}{\delta^{2} \mathrm{Ph}}
$$

as suggested by Lothrop et al. (1985).

Rank summation index (RSI) described by Mulamba and Mock (1978) was used to rank each of the 97 progenies using the most economic sugarcane traits viz: cane 
yield and brix. This approach was used to select the top $20 \%$.

\section{Result}

The combined analysis of variance showed differences in the expression of the characters were significant at each of the crop cycles (CC) (Table 1). The genotypes (G) also differed significantly (P $0.05 \leq$ 0.001) for all the traits while CC x G only differed significantly for cane yield and brix.

Performances of the genotypes were not consistent across the three crop cycles (Table 2). For example stalk length, stalk diameter and internodes/stalk declined steadily over the three crop cycles by $(2.7$ and $8.5 \mathrm{~cm}),(0.04$ and $0.21 \mathrm{~cm})$ and $(4$ between crop cycles) in the first and second ratoons. Millable cane population, cane yield and brix on the other hand were higher in the first ratoon relative to the plant crop by $\left(12.00,11.24\right.$ tonsha $^{-1}$ and $1.60)$ but declined between the first and second ratoon crops by $\left(2.00,1.92\right.$ tons $/ \mathrm{ha}^{-1}$ and 1.20).

In general, the phenotypic variance $\left(\delta^{2} \mathrm{ph}\right)$ estimates were higher than the genotypic variance $\left(\delta^{2} \mathrm{~g}\right)$ estimate for all the traits except for stalk length (Table 3). Estimates of progeny $x$ crop cycle variance $\left(\delta^{2}\right.$ gcc) was negative for stalk length, stalk diameter and internodes/stalk as estimates of mean square error (Mse) were greater in magnitude than estimates of mean square for G x CC (Msge) interaction. Broad sense heritability $\left(\mathrm{H}^{2} \mathrm{~B}\right)$ estimates ranged from $21.02 \%$ for millable cane population to $79.63 \%$ for cane yield. High to moderate heritability estimates were obtained for all yield related traits expect millable cane population which recorded low estimate similar to brix with $37.09 \%$ heritability estimate.
Identification of the top $10 \%$ among the progenies based on combination of cane yield and brix (Table 4) revealed that there was alteration in the ranking of the genotypes in each of the three crop cycles. However, three progenies (USRI/08/12, USRI/08/22 and USRI/08/25) were among the top ten genotypes in each of the three cropping cycles. Of the three progenies, USRI/08/22 was the most consistent, ranking top in the ratoon crops and second in the plant crop. Two other progenies (USRI/08/43 and USRI/08/22) also showed superiority of performance in the plant and first ratoon crops respectively.

The contribution of maternal parents to the 13 progenies selected for the next stage of performance evaluation based on the minimum acceptable sucrose content $(\geq 18)$ in our breeding programme (Table 5) revealed that four parents (B 4681, B 014, B 74139 and D 141146) contributed two (2) genotypes each, five (5) others (Co 945, CP 70-1138, M 60270, S 17 and SP 7116) contributed one (1) genotype each while the remaining twenty-seven maternal parents did not contributed any genotype to the next selection stage. Four of the progenies (USRI/08/10, USRI/08/12, USRI/08/22 and USRI/08/25) in that order showed superiority over the best three (3) checks for both cane yield and sucrose content.

\section{Discussion}

The significant differences observed for all the characters in each of the crop cycles (CC) and G x CC interaction for cane yield, brix and millable cane population is an indication of differences in performance of the genotypes in each of the crop cycles, which may be due to reduced vigor usually associated with ratoon crops in sugarcane (Olaoye, 1995; 2001). Furthermore, the large variability obtained for most of the traits especially millable cane population 
and number of internodes/stalk suggest the presence of genetic variability among the populations consequently high level of genetic recombination as exploited in the breeding scheme.

Surprisingly, fluctuation in the mean of cane yield and related traits from each crop cycle showed that apart from decline in vigor of sugarcane in ratoon crops, timely harvest can also contribute to differences in performance. For example, the high number of internodes/stalk, millable cane population and brix obtained in the first ratoon compared to the plant crop was due to delay in harvesting the plant crop which resulted in the death of many of stalks especially among the flowering genotypes.

The magnitude of the estimates of the mean squares due to error $\left(\mathrm{Ms}_{\mathrm{e}}\right)$ were larger for almost all the characters compared to the mean squares due to $\mathrm{G}$ x CC $\left(\mathrm{Ms}_{\mathrm{gcc}}\right)$ interaction and the preponderance of the negative estimates observed in this study, may be due to the death of stalks of the flowering type among the progenies occasioned by the prolonged delay in harvesting the plant cane, thereby resulting in the large plot-to-plot variability in the subsequent ratoon crops. This observation is similar to reports obtained from earlier studies (Olaoye and Fatunla, 1991; Olaoye, 1995).

Variability and heritability are important tools, which breeders explore in defining selection criteria. The high to moderate estimates of broad sense heritability obtained in this study for cane yield and related traits suggest existence of genetic variability among the populations sampled, thus evidence of genetic mixed up resulting from the crosses made through the technique. The low heritability estimate obtained in respect of brix is connected to low genetic variability among the progenies for this trait; however there is always a minimum acceptable standard for this trait in sugarcane breeding programmes. In lieu of this the low heritability estimate obtained for brix may not be connected to the adopted breeding scheme but rather the genetic make-up of the parental materials used in making crosses. Reports from several studies conducted in Nigeria and elsewhere (Olaoye and Fatunla, 1991; Olaoye, 1995; Chaudhary, 2001; Ishaq and Olaoye, 2006) have also shown that heritability is a property of the population being sampled and/or environmental conditions under which such estimates were obtained. For example while low broadsense heritability estimate $(49 \%)$ was reported for cane yield in a study involving exotic and local sugarcane populations (Olaoye and Fatunla, 1991, high cane yield but low sucrose content was recorded for local sugarcane populations (Olaoye, 1995). Conversely, high narrowsense heritability $\left(\mathrm{H}^{2} \mathrm{~N}\right)$ was reported for cane yield in another study which involved progenies derived from bi-parental crosses (Ishaq and Olaoye, 2006).

The emergence of different genotypes as top $10 \%$ in each crop cycle using the RSI indicate the existence of a negative correlation between the two traits and that different gene(s) were responsible for each trait. The incongruence of high cane yield and high sucrose content in most genotypes is undesirable since commercial acceptability of a sugarcane variety is usually based on its ability to combine high cane tonnage with acceptable sucrose content. This may be connected with the fact that the parents currently used in crosses are still the first or second generations of clones imported into the country at the commencement of commercial plantation in Nigeria. Nevertheless, four maternal parents (B4681, D141146, B74139 and B 014) 
each contributed two candidates to the next stage of yield testing while five other maternal parents contributed one genotype each. This implies that hybridization efforts could be concentrated on this few maternal parents so that greater number of superior progenies can be contributed to our sugarcane varietal development activities. Therefore, in order to make a faster progress in our breeding programme, it will be necessary to inject newer and high yielding sugarcane germplasm accessions through importation from countries with similar climatic conditions like Nigeria.

Overall, the superiority of progenies USRI/08/10, 12, 22 and 25 over the standard local check shows the appropriateness and efficacy of modified polycross method in development of economical sugarcane varieties for low technological development country like Nigeria.

\section{Conclusion}

The modified polycross method is efficient in development of improved sugarcane varieties. This technique is however laborious and required prior understanding of the flowering pattern of the genotypes. Nonetheless, it cheap and required little technical know-how unlike the Hawaiian polycross technique; consequently it recommended for use in low resource sugarcane breeding programme.

\section{References}

Chaudhary, R.R, (2000/2001). Genetic Variability and Heritability in Sugarcane. Nepal Agric. Res. J., Vol. $4 \& 5$.

Falconer, D.S. (1966). Heritability and Repeatbility Discussion. Int. Soc.
Sugar Technol. Sugarcane Breeder's Newsletter.18:1517.

FAOSTAT. (2011). http://faostat.fao.org. Ishaq, M.N. and Olaoye, G. (2006). Estimate of variance components and heritability in sugarcane under moisture stress and non-moisture stress conditions. Nigerian J. Genetics. 20: 33-40.

Ishaq, M.N. and Olaoye, G. (2008). Expression of heterosis in sugarcane genotypes under moisture stressed condition. African Journal of General Agriculture. 4(2): 99-105.

Lothrop, J.E., Atkin, R.E. and Smith, O.S. (1985). Variability for yield and yield components in IAPIR grain sorghum random mating population. I. Means, variance components and heritabilities. Crop Sci. 25: 235-240.

Mulamba, N.N. and Mock, J.J. (1978). Improvement of Yield potential of Eto Blanco Maize (Zea mays) population by breeding for plant triats. Egypt Journal of Genetic.7: 4051.

Olaoye, G. (1995). Evaluation of Local Sugarcane Accessions: (I) Breeding Values in Main and Ratoon Crops. Nigeria J. Genet., X, 14-22.

Olaoye G. (2001). Genetic Variability Between and Within Progenies of Sugarcane Crosses Developed by Modified Polycross Method at the Seedling Selection Stage. Ghana Jnl Agric. Sci., 34, 101-107.

Olaoye, G. (2005). Estimates of ratooning ability in sugarcane (Saccharum officinarum L.) under conditions of low- available soil moisture in a savanna ecology of Nigeria. Moor Journal of Agricultural Research 6(1): 16-23.

Olaoye, G. (2006). Yield potential of nonirrigated sugarcane germplasm 
accessions in a savanna ecology of Nigeria. Moor Journal of Agricultural Research, 7(2): 69-75.

Olaoye, G. and Fatunla, T. (1991). Variance Components, Heritability and Repeatability of Some Quantitative Characters in Sugarcane (Saccharum officinarum). Nigeria J. Genet., VIII, 31-38.

Ramalho, M.AP., Santos, J.B., dos Pinto, C.A.B.P. (2004). Genetica na agropecuaria. Lavras:UFLA. Pp 472483

Resende, M.D.V, and Barbosa, M.H.P. (2006). Selection via simulated BLUP based on family genotypic effects in sugarcane. Pesquisa Agropecuaria Brasileira: Brasilia, 41: 421-929
Singh, H.N., Singh, S.B. and Singh, T.K (1981). Selection parameter in sugar cane. Indian J. Agric. Sc. 53(9):786789.

Singh, H.N., Singh, S.B., Chanhan, R.V.S. and Vishwarkarma, R.S. (1983). Variability for yield and quality in sugar cane. Indian J. Agric. Sci. 53(9): 786-789.

Soomoro, A., Junejo, S., Ahmed, A. and Salam, M. (2006). Evaluation of different promising sugarcane varieties for some quantitative and qualitative attributes under Tahtta (Pakistan) conditions. Int. J. of Agric. and Biology. 8(2): 195-197.

Table 1: Mean squares from the combined ANOVA over three crop cycles for cane yield and related traits in 97 sugarcane progenies developed by the modified polycross method at the seedling selection stage (Ilorin, 2009-2011).

\begin{tabular}{|c|c|c|c|c|c|c|c|}
\hline $\begin{array}{l}\text { Source } \\
\text { of variation }\end{array}$ & $\mathrm{df}$ & $\begin{array}{l}\text { Stalk } \\
\text { length }\end{array}$ & $\begin{array}{l}\text { Stalk } \\
\text { diameter }\end{array}$ & $\begin{array}{l}\text { Internodes/ } \\
\text { stalk }\end{array}$ & $\begin{array}{l}\text { Millable } \\
\text { cane }\end{array}$ & $\begin{array}{l}\text { Cane yield } \\
\left(\text { tonsha }^{-1}\right)\end{array}$ & $\begin{array}{l}{ }^{\circ} \text { Brix } \\
(12 \mathrm{MAP})\end{array}$ \\
\hline Replicate & 1 & 3188.6 & 0.35 & 28.39 & 2373.0 & 15.95 & 0.09 \\
\hline $\begin{array}{l}\text { Cropping } \\
\text { Cycle (CC) }\end{array}$ & 2 & $6685.0 * *$ & $3.34 * *$ & $2785.00 * *$ & $8425.0 * *$ & $3941.49 * *$ & $136.19 * *$ \\
\hline Genotype (G) & 96 & $1348.0 * *$ & $0.27 * *$ & $28.74 * *$ & $309.2 *$ & $435.29 * *$ & $11.87 * *$ \\
\hline $\mathrm{G} \times \mathrm{CC}$ & 192 & 568.0 & 0.09 & 10.81 & 243.0 & $66.96^{* *}$ & $5.78 * *$ \\
\hline Pooled Error & 290 & 608.2 & 0.13 & 16.37 & 23.6 & 12.57 & 0.29 \\
\hline
\end{tabular}

*, **; significant $\mathrm{F}$ Test at 0.05 and 0.01 levels of probability respectively

Table 2: Means in each crop cycle for cane yield and related traits in 97 sugarcane progenies developed by the modified polycross method (Ilorin, 2011).

\begin{tabular}{llllllr}
\hline Crop cycle & $\begin{array}{l}\text { Stalk } \\
\text { length } \\
(\mathrm{cm})\end{array}$ & $\begin{array}{l}\text { Stalk } \\
\text { diameter } \\
(\mathrm{cm})\end{array}$ & $\begin{array}{l}\text { Internodes/s } \\
\text { talk }(\mathrm{no})\end{array}$ & $\begin{array}{l}\text { Millable } \\
\text { cane (no) }\end{array}$ & $\begin{array}{l}\text { Cane yield } \\
\left(\text { tonsha- }^{1}\right)\end{array}$ & $\begin{array}{l}{ }^{\circ} \text { Brix } \\
(12 \mathrm{MAP})\end{array}$ \\
\hline Plant crop & 143.30 & 2.31 & 16.00 & 23.00 & 30.91 & 17.30 \\
First ratoon & 140.60 & 2.27 & 12.00 & 35.00 & 42.15 & 18.90 \\
Second ratoon & 132.10 & 2.06 & 8.00 & 33.00 & 40.23 & 17.70 \\
LSD $\alpha 0.05$ & 4.93 & 0.07 & 0.81 & 3.04 & 0.71 & 0.11 \\
\hline
\end{tabular}


Table 3: Variance components and broadsense heritability estimates for cane yield and associated traits in 97 sugarcane progenies developed by the modified polycross method at the seedling selection stage (Ilorin, 2011).

\begin{tabular}{llllll}
\hline Characters & $\begin{array}{l}\text { Error } \\
\text { variance } \\
\left(\sigma^{2} \mathrm{e}\right)\end{array}$ & $\begin{array}{l}\text { Interaction } \\
\text { variance } \\
\left(\sigma^{2} \mathrm{gcc}\right)\end{array}$ & $\begin{array}{l}\text { Genotypic } \\
\text { variance } \\
\left(\sigma^{2} \mathrm{~g}\right)\end{array}$ & $\begin{array}{l}\text { Phenotypic } \\
\text { variance } \\
\left(\sigma^{2} \mathrm{eph}\right)\end{array}$ & $\begin{array}{l}\text { Broadsense } \\
\text { heritability } \\
\left(\mathrm{h}^{2} \mathrm{~b}\right)\end{array}$ \\
\hline $\begin{array}{l}\text { Stalk length } \\
\text { Stalk diameter }\end{array}$ & 608.20 & -20.10 & 130.0 & 221.32 & 58.74 \\
$\begin{array}{l}\text { Internodes/stalk } \\
\text { Millable canes }\end{array}$ & 13.00 & -0.02 & 0.03 & 0.04 & 75.00 \\
$\begin{array}{l}\text { Cane yield } \\
\left.\text { tonsha }^{-1}\right)\end{array}$ & $\begin{array}{l}231.60 \\
{ }^{\circ} \text { Brix }(12 \mathrm{MAP})\end{array}$ & $\begin{array}{l}-2.78 \\
5.70\end{array}$ & 3.01 & 4.35 & 69.19 \\
\hline
\end{tabular}


Table 4: Selection of the top $10 \%$ based on combination of cane yield and sucrose content among 97 sugarcane progenies in the three harvest stages

\begin{tabular}{|c|c|c|c|c|c|c|c|c|c|c|c|c|c|c|}
\hline \multirow[b]{2}{*}{$\begin{array}{l}\text { Progeny } \\
\text { Code }\end{array}$} & \multicolumn{2}{|c|}{ Plant crop } & \multirow[b]{2}{*}{$\sum \mathrm{RSI}$} & \multirow[b]{2}{*}{ Rank } & \multirow[b]{2}{*}{$\begin{array}{l}\text { Progeny } \\
\text { Code }\end{array}$} & \multicolumn{2}{|c|}{ First Ratoon Crop } & \multirow[b]{2}{*}{$\sum \mathrm{RSI}$} & \multirow[b]{2}{*}{ Rank } & \multirow[b]{2}{*}{$\begin{array}{l}\text { Progeny } \\
\text { Code }\end{array}$} & \multicolumn{2}{|c|}{ Second Ratoon Crop } & \multirow[b]{2}{*}{$\sum \mathrm{RSI}$} & \multirow[b]{2}{*}{ Rank } \\
\hline & $\begin{array}{l}\text { Cane } \\
\text { yield } \\
\text { (tons/ha) }\end{array}$ & $\begin{array}{l}{ }^{\circ} \text { Brix } \\
(12 \text { MAP) }\end{array}$ & & & & $\begin{array}{l}\text { Cane } \\
\text { yield } \\
\text { (tons/ha) }\end{array}$ & $\begin{array}{l}{ }^{\circ} \text { Brix } \\
(12 \mathrm{MAP})\end{array}$ & & & & $\begin{array}{l}\text { Cane } \\
\text { yield } \\
\text { (tons/ha) }\end{array}$ & $\begin{array}{l}{ }^{\circ} \text { Brix } \\
(12 \mathrm{MAP})\end{array}$ & & \\
\hline
\end{tabular}

\begin{tabular}{|c|c|c|c|c|c|c|c|c|c|c|c|c|c|c|}
\hline USRI/08/43 & $70.7(1)$ & $20.0(21)$ & 22 & $1^{\text {st }}$ & USRI/08/22 $2^{+}$ & $72 . .6(5)$ & $21.4(4)$ & 9 & $1^{\text {st }}$ & USRI/08/22 $2^{+}$ & $62.0(6)$ & $21.1(7)$ & 11 & $1^{\mathrm{st}}$ \\
\hline USRI/08/22 $2^{+}$ & $53.7(20)$ & $21.0(4)$ & 24 & $2^{\text {nd }}$ & USRI/08/83 & $57.3(23)$ & $22.3(5)$ & 28 & $2^{\text {nd }}$ & USRI/08/10 & $58.9(8)$ & $21.3(5)$ & 13 & $2^{\text {nd }}$ \\
\hline USRI/08/37 & $52.2(24)$ & $21.5(3)$ & 27 & $3^{\mathrm{rd}}$ & USRI/08/12 $2^{+}$ & $58.4(20)$ & $21.6(10)$ & 30 & $3^{\text {rd }}$ & USRI/08/25 $5^{+}$ & $58.9(8)$ & $21.1(7)$ & 15 & $3^{\text {rd }}$ \\
\hline USRI/08/78 & $62.4(15)$ & $20.5(12)$ & 27 & $4^{\text {th }}$ & USRI/08/75 & $63.5(4)$ & $18.7(28)$ & 32 & $4^{\text {th }}$ & USRI/08/12 $2^{+}$ & $57.9(10)$ & $20.8(13)$ & 23 & $4^{\text {th }}$ \\
\hline USRI/08/62 & $52.4(25)$ & $21.0(4)$ & 29 & $5^{\text {th }}$ & USRI/08/53 & $58.4(20)$ & $21.2(15)$ & 35 & $5^{\text {th }}$ & USRI/08/63 & $62.9(5)$ & $16.0(21)$ & 26 & $5^{\text {th }}$ \\
\hline USRI/08/87 & $67.9(8)$ & $20.0(21)$ & 29 & $6^{\text {th }}$ & USRI/08/25 & $60.1(17)$ & $21.0(20)$ & 37 & $6^{\text {th }}$ & USRI/08/50 & $56.1(12)$ & $20.2(17)$ & 29 & $6^{\text {th }}$ \\
\hline USRI/08/93 & $60.5(17)$ & $20.5(12)$ & 29 & $7^{\text {th }}$ & USRI/08/57 & $62.4(6)$ & $19.3(38)$ & 44 & $7^{\text {th }}$ & USRI/08/59 & 47.7(39) & $21.4(4)$ & 43 & $7^{\text {th }}$ \\
\hline USRI/08/25 ${ }^{+}$ & $67.3(9)$ & $20.0(21)$ & 30 & $8^{\text {th }}$ & USRI/08/43 & $42.4(32)$ & $21.3(12)$ & 44 & $8^{\text {th }}$ & USRI/08/66 & $50.7(33)$ & $21.0(10)$ & 43 & $8^{\text {th }}$ \\
\hline USRI/08/12 $2^{+}$ & $53.5(21)$ & $20.5(12)$ & 33 & $9^{\text {th }}$ & USRI/08/01 & $40.3(43)$ & $21.6(4)$ & 47 & $9^{\text {th }}$ & USRI/08/38 & $47.7(39)$ & $21.7(7)$ & 46 & $9^{\text {th }}$ \\
\hline USRI/08/92 & $62.0(16)$ & $20.0(21)$ & 37 & $10^{\text {th }}$ & USRI/08/62 & $42.0(33)$ & $20.3(14)$ & 47 & $10^{\text {th }}$ & USRI/08/52 & $42.7(44)$ & $21.2(6)$ & 50 & $10^{\text {th }}$ \\
\hline
\end{tabular}


Table 5: Contribution of maternal parents to progenies selected for stage II evaluation based on combination of cane yield and acceptable sucrose content (Ilorin, 2011)

\begin{tabular}{|c|c|c|c|c|}
\hline $\mathrm{S} / \mathrm{N}$ & Progeny & Cane yield $\left(\mathrm{t} / \mathrm{ha}^{-1}\right)$ & ${ }^{\circ}$ Brix & Maternal parent \\
\hline 1. & USRI/08/22 & 62.00 & 21.1 & Co945 \\
\hline 2. & USRI/08/10 & 58.90 & 21.3 & B 4681 \\
\hline 3. & USRI/08/25 & 58.90 & 21.3 & B 74139 \\
\hline 4. & USRI/08/12 & 57.90 & 20.8 & D141146 \\
\hline 5. & USRI/08/50 & 56.10 & 20.2 & В 014 \\
\hline 6. & USRI/08/66 & 50.70 & 21.0 & M 60270 \\
\hline 7. & USRI/08/46 & 52.73 & 19.8 & S 17 \\
\hline 8. & USRI/08/75 & 62.00 & 19.6 & В 014 \\
\hline 9. & USRI/08/55 & 51.63 & 19.5 & SP 7116 \\
\hline 10. & USRI/08/59 & 47.70 & 21.4 & B 4681 \\
\hline 11. & USRI/08/38 & 47.70 & 21.7 & СР 70-1138 \\
\hline 12. & USRI/08/28 & 49.29 & 20.2 & D141146 \\
\hline 13. & USRI/08/53 & 44.21 & 19.8 & B74139 \\
\hline \multicolumn{5}{|c|}{ Best three checks } \\
\hline 1. & ILS-002 & 57.34 & 19.5 & \\
\hline 2. & Co62175 & 56.90 & 20.1 & \\
\hline 3. & Co 957 & 42.36 & 20.3 & \\
\hline \multicolumn{2}{|c|}{ LSD $\alpha 0.05$} & 11.21 & 2.91 & \\
\hline
\end{tabular}

